\title{
Silence, an Eye of Knowledge
}

\author{
Mehdi Aghamohammadi \\ Department of English Language and Literature, Azarbaijan Shahid Madani University, Iran \\ E-mail: mrmehdi.ir@gmail.com
}

Received: 23-02-2017

Accepted: $30-03-2017$

Published: $30-04-2017$

doi:10.7575/aiac.ijels.v.5n.2p.20

URL: http://dx.doi.org/10.7575/aiac.ijels.v.5n.2p.20

\begin{abstract}
One of the conspicuous features of the twentieth-century West was silence. This idea could be supported by examining reflections of Ludwig Wittgenstein, Fritz Mauthner, John Cage, Samuel Beckett, Ihab Hassan, Franz Kafka, Wassily Kandinsky, Jean-Paul Sartre, Virginia Woolf, Wolfgang Iser, Jacques Derrida, and Pierre Macherey. To me, silence is not a mere theory, but rather a phenomenon from which we can get practical benefits. I believe silence is an eye, eye of knowledge. We can broaden our knowledge of the world through silence. To convey the idea that silence is an eye, I have concocted the word $\mathrm{s} \odot$ lence, where $\odot$ has replaced the letter $\mathrm{i}$ and stands for the eye. This means knowledge can enable us to see, thereby acquiring knowledge of, what used to be invisible, and accordingly unknowable. In other words, through silence, we can achieve a certain type of literacy. I substantiate this claim by exploring the Horus myth, Ojo de Dios, John Cage's 4' 33", the nature of Expressionist paintings, Hinduism, thoughts of Hermes Trismegistus and Ibn al-Arabi, and practices of Mohammad, the prophet of Islam.
\end{abstract}

Keywords: Eye, John Cage, Knowledge, Silence, Twentieth Century

\section{Introduction}

Knowledge can deepen our understanding and increase the possibility of our success in life. Definitely, no human being wants to remain in ignorance. Abandoning it and moving toward the acquirement of knowledge are in our nature. In fact, humans have always been fond of learning. A large number of prominent figures, particularly philosophers, have pondered over this important topic and tried to offer answers to relevant questions as to, for example, what knowledge is, what limits of our knowledge are, and how we know what we know. The present article aims to introduce a novel approach to the attainment of knowledge. In my view, silence has the potential to open some gates of the unknown. Due to this, I believe silence is an eye of knowledge. John Cage's 4' 33", the Horus myth, and Ojo de Dios are appropriate examples to clarify my meaning. I am also going to investigate the nature of Expressionist paintings, a few beliefs in Hinduism, thoughts of Hermes Trismegistus and Ibn al-Arabi, and practices of Prophet Mohammad so as to flesh out my argument. The reason why I spotlight silence is that it was one of the distinctive features of the twentieth-century West. In this article, I stress that we can apply silence to gain knowledge and achieve a particular type of literacy.

In the following sections of the article, I will first expand on the term silence and then the condition of the twentiethcentury West with regard to silence, exploring reflections of Ludwig Wittgenstein, Fritz Mauthner, John Cage, Samuel Beckett, Ihab Hassan, Franz Kafka, Wassily Kandinsky, Jean-Paul Sartre, Virginia Woolf, Wolfgang Iser, Jacques Derrida, and Pierre Macherey. Next, I will give a short overview of knowledge and present renowned figures' thoughts on it. I will finally elucidate my coinage s๑lence and will substantiate the claim that silence is an eye of knowledge through some relevant examples.

\section{Silence}

Silence has been explored from perspectives as varied as pragmatics, social psychology, anthropology, sociolinguistics, semiotics, and intercultural communication (Nakane, 2012, p. 158). In Silence: The phenomenon and its ontological significance (1980), Bernard P. Dauenhauer, Professor Emeritus of Philosophy at the University of Georgia, argues that silence is never the absence of meaning, but rather it is a positive phenomenon. His attempt "to examine and establish the ontological status of silence is a notable exception to the fact that systematic philosophical discussion has lagged behind artists' efforts to relate the importance of the elusive phenomenon of silence" (Circosta, 2005, p. 139). In discussions pertaining to the colonial and postcolonial discourse, "silence has been read as a many-accented signifier of disempowerment and resistance, of the denial of a subject position and its appropriation" (Parry, 1996, p. 43).

It must be mentioned that silence is of different sorts. The French philosopher and literary critic Michel Foucault (19261984) wrote,

Silence itself - the things one declines to say, or is forbidden to name, the discretion that is required between different speakers - is less the absolute limit of discourse, the other side from which it is separated by a strict boundary, than an element that functions alongside the things said, with them and in relation to them within 
over-all strategies. . . . There is not one but many silences, and they are an integral part of the strategies that underlie and permeate discourses. (1980, p. 27)

Silence can be self-imposed or the result of external constraints; it can be expressive or unreadable; it can signify attentive listening or withdrawal from a conversation; even it can be temporary or consistent (Burbules, 2005, p. xxiv). Silence can be a religious or mystical element. Religious silence can be divine or demonic (Zijlstra, 2006, p. 93). The Polish philosopher Izydora Dąmbska (1904-1983) argues:

Literature uses silence in two ways: indirect and direct. The direct one occurs when an author speaks of the silence of a literary character as a word or a behavior pattern, etc. . . The indirect one occurs in the form of a pause, omission, understatement, or falling silent, for instance in a poem or a song, in silence as the expression of characters on the stage in a drama. A theatrical play uses silence as a means of artistic expression with the most clarity. (2016, p. 317)

This was a literary perspective. In the world of literature, there are numerous references to silence. For example, in What happened: A five act play, the American playwright Gertrude Stein (1874-1946) writes that "silence is so windowful" (1993, p. 205). Besides punning on the word wonderful, the sentence suggests that, through silence, several windows of thoughts and perspectives open to us. Similarly, Molana Jalal ad-Din Mohammad, also known as Rumi or Molavi, (1207-1273), a distinguished Persian poet and mystic, said,

خاموشى بحر است و كفتن همجو جو / بحر مىجويد نو را جو را مجو (Molavi, 1987, Couplet 2064)

My translation reads as follows:

Silence is the sea and speech like the brook;

The sea is seeking you; do not seek the brook.

Sociologically, it is contended that for a stranger who enters "an alien society, a knowledge of when not to speak may be as basic to the production of culturally acceptable behavior as a knowledge of what to say" (Basso, 1970, p. 215). Georges Bataille (1897-1962), a French intellectual and writer, provides a novel understanding of silence by comparing it to nudity. In his opinion,

Silence, like death, is not something simply waiting for us, or that was always there - it is something that is "always already" there, that arrives as a function of life, of language. Silence is to language what nudity is to clothes - not separate, but absolutely linked. Nudity and silence can only exist after their annulment in clothes or words, and will then be seen as the primordial condition. (Hegarty, 2000, p. 158)

Extending Bataille's idea, I think silence exists after the "annulment" of images, light, sound, words, voice, the visible, the feelable, and even the tastable. However, such a broad understanding of silence requires us to take the context into account. For example, as compared with a face with make-up, a face without make-up is silent. A man without a beloved is silent, in comparison with a man who has a beloved.

Psychotherapy, particularly psychoanalysis, is also deeply involved with the study of silence. It has realized and explored various types and functions of silence in the therapeutic discourse. For example, this discipline regards silence as a way of not only acting-out but also communication (Ephratt, 2008, p. 1933). For instance, Theodor Reik (18881970), an Austrian psychoanalyst, wrote: "There is meaningless speech and meaningful silence" (1968, p.183).

Silence is also of great significance in political science. One of the most important theories in it, and also in mass communication, is the "spiral of silence," which was formulated by Elisabeth Noelle-Neumann (1916-2010), a German political scientist, in the early 1970s.

The spiral of silence model assumes that people are constantly aware of the opinions of people around them and adjust their behaviors (and potentially their opinions) to majority trends under the fear of being on the losing side of a public debate. In particular, Noelle-Neumann based her theorizing on the premise that individuals have a 'quasistatistical sense' that allows them to gauge the opinion climate in a society, i.e., the proportions of people who favor or oppose a given issue. This quasi-statistical sense may be accurate, but very often it is not, i.e., people are wrong in their assessments of what everyone else thinks. (Scheufele, 2008, p. 175)

Undoubtedly, linguists are also interested in silence. However, generally speaking, according to the outstanding Spanish scholar Fernando Poyatos (b. 1933), 
Linguistics has wasted many research opportunities offered by silence. It has concentrated solely on certain silences of discourse, the so-called internal junctures (within a word), external junctures (between words) and terminal junctures (at the end of sentences), and on some attitudinal silences . . . Rarely have linguists referred to silence as a component of interaction, thus missing the fact that when speech is interrupted by a 'pause,' at least one of the other two co-occurring activities, paralanguage or kinesics, still fill that apparent (never semiotically) gap. (2002, p. 299)

In The functions of silence (2008), Michal Ephratt, an Israeli professor of linguistics, differentiated pause from "(eloquent) silence," which is neither the silencing of the speaker nor the listener's silence but a means for verbal communication. She additionally explored the roles of (eloquent) silence in the six functions of language in Roman Jakobson's communicative model (1960). Ephratt wrote:

(Eloquent) silence, as a linguistic sign, conveys information in the referential function (zero-sign and passive constructions); it is an iconic affective way of expressing emotions (e.g., emptiness, intimacy) in the emotive function. In respect of the conative function, (eloquent) silence performs direct and indirect speech acts. Caesura, metaphors and ellipses are just a few examples of poetic silence. Silence is a means of maintaining contact and alliance in the phatic function. The various roles of silence in the metalinguistic function range from its being a discourse marker to reflecting the 'right to silence'. (2008, p. 1909)

The examples I presented and explored in this section show that myriads of disciplines have underscored the significance of silence. The following section will delve into this phenomenon in the twentieth century.

\section{Silence in the Twentieth Century}

The West in the twentieth century had conspicuous features one of which was silence. In fact, it was a century preoccupied with silence. A brief comparative look at the cultural difference between ancient Greece, as not only "the birthplace of Western civilization" (Colt, 2006, p. 144) but also "the intellectual and administrative backbone to" Western civilization (MacKinnell, 2011, p. 95), and the twentieth-century West substantiates the claim:

THE ANCIENT Greeks had a culture of the spoken word. . . The spoken word was everywhere: in the theater, in the assembly, in ritual settings. Experiences that are normally silent for us were normally vocal for a Greek, at least in the archaic and classical periods. We usually enjoy poetry in privacy, in solitude; the Greeks enjoyed poetry in performance, as collective audiences rather than as individuals. We read more, they heard more. Reading itself was a vocal act. So were praying and mourning. (Montiglio, 2000, p. 3)

In fact, the twentieth-century West was engrossed in silence much more than its background, which was predominantly vocal. Hence, a "striking feature of twentieth-century Western cultural history was a preoccupation with silence" (Dauncey, 2003, p. vii). It was no coincidence that the twentieth century had two more striking features related to silence: 1) scientific, medical, and technological advances particularly since the first half of the century; 2) dominance "by visual rather than oral or textual media" (Sturken \& Cartwright, 2001, p. 1). (I will explain the first feature later in the present paper.)

Furthermore, in the twentieth century, for the first time, painting articulated "its own language" (Hodge, 2008, p. 141). Considering that "painting neither uses words [unlike drama] nor makes sounds [unlike music]" (Bae, 2006, p. 7), one could say, whatever language it was, the language of twentieth-century painting was still silent. Abstract painting highlighted this silence. Expressionism as one of the twentieth-century art movements contributed to abstract art and the century's silent language. Hermann Bahr (1863-1934), an Austrian author, compared an Expressionist painter to a musician, "of whom we do not ask that he shall reproduce sounds heard in the outside world, but that he shall produce out of himself what he hears within himself. Expressionist painting is 'eye-music"” (Boyd, 1925, pp. 234-35).

That silence was one of the key features of the twentieth-century West could be substantiated by exploring reflections of Ludwig Wittgenstein, Fritz Mauthner, John Cage, Samuel Beckett, Ihab Hassan, Franz Kafka, Wassily Kandinsky, Jean-Paul Sartre, Virginia Woolf, Wolfgang Iser, Jacques Derrida, and Pierre Macherey.

Wittgenstein (1889-1951), "the most influential, and arguably the greatest, philosopher of the twentieth century" (Richter, 2004, p. 1), concluded Tractatus logico-philosophicus (1921) with the following proposition: "What we cannot speak about we must pass over in silence" $(1961, \S 7)$. Arguing that postmodernist novelists "seek silence by abandoning the traditional elements of fiction such as character, plot, metaphor, and meaning," Ihab Hassan (b. 1925), an American literary theorist, posits that "there is an inexorable movement towards silence" (Woods, 1999, p. 52). Fritz Mauthner (1849-1923), a German philosopher of language, argued that "verbalization destroys the uniqueness of thought." He exhorted "thinkers to the condition of silence" (Shaw-Miller, 2002, p. 262, note 12). John Cage (19121991), an American composer, and Samuel Beckett (1906-1989), an Irish playwright and novelist, "explored and redefined" silence and "some of their pieces focused on silence" (Weagel, 2002, p. 249). 
Franz Kafka (1883-1924), a Czech writer whose works were in German, wrote a different version of the story of the Sirens in late October of 1917. Canonically, the story was as follows:

The Sirens were three beautifully singing female monsters whose heads were human and bodies avian. They seduced sailors with their singing, luring them to inevitable shipwreck on their island - sometimes thought to be Sicily. Odysseus knew about the Sirens and, always curious, wanted to hear them. To prevent tragedy, he sealed up the ears of his sailors and had himself tied to his mast as his ship sailed by the monsters. The Argonauts, too, sailed by unscathed, as Orpheus's even more beautiful music overcame that of the Sirens and, as foretold, the monsters threw themselves, defeated, into the sea. (Leeming, 2005, p. 358)

However, in Kafka's short story, posthumously entitled Das Schweigen der Sirenen (German, "The silence of the Sirens") and published in 1931, Kafka's Odysseus differs from Homer's. He has himself bound to the mast and also seals up his own ears with wax, but not those of his crew. However, ironically, the Sirens do not sing at all. On the one hand, Odysseus does not know that there is nothing to hear and therefore, mistakenly, has the idea that his trick has worked. Yet, on the other hand, he may not be wrong because the Sirens are seduced by the look of bliss on Odysseus's face and forget singing. Moreover, for a moment, he sees them move their throats with half-parted lips, lift their breasts, and gaze with tearful eyes. Odysseus interprets these gestures as accompaniments to their song. He ultimately sails away and the Sirens lose as well as win. The Sirens' song is “equivalent to the modern condition" (Kramer, 2006, pp. 202-3).

Wassily Kandinsky (1866-1944), a Russian painter, who "is generally considered to be the pioneer of abstract painting" (Hodge, 2008, p. 158) extended silence to painting. The following rationale substantiates the claim: "The fundamental medium of communication in painting is in shapes and colours, and silence in painting can be expressed by the absence of these crucial materials. . . [A]bstract painting embodies silence in that it misses definite shapes and thereby arouses ambiguity, an essential characteristic of silence" (Bae, 2006, p. 7).

According to Jean-Paul Sartre (1905-1980), a French philosopher and writer, his contemporary writers suffered from "a common disease" which he called "the obsession with silence." In his opinion,

[Silence] has assumed a thousand forms, ranging from the surrealists' automatic writing to Jean-Jacques Bernard's "theatre of silence." The reason is that silence, as Heidegger says, is the authentic mode of speech. Only the man who knows how to talk can be silent. M. Camus talks a great deal; in The Myth of Sisyphus he is even garrulous. And yet, he reveals his love of silence. He quotes Kierkegaard: "The surest way of being mute is not to hold your tongue, but to talk." And he himself adds that "a man is more of a man because of what he does not say than what he does say:" Thus, in The Outsider, he has attempted to be silent. (Sartre, 1962, p. 36)

Virginia Woolf (1882-1941), an English writer and critic, was the "first woman novelist in Modernity to practice silence rather than speech" (Laurence, 1991, p. 1). She deployed silence in a most complex way. Silence held her attention from the beginning of her career with The voyage out (1915) through to her last work Between the acts (1941), the title of which hints at the significance of silence in between (Circosta, 2005, p. 139). In The voyage out, a young, aspiring writer says, "I want to write a novel about Silence," about "the things people don't say. But the difficulty is immense" (Woolf, 1990, p. 216).

Gaps, blanks, or lacunae in a text are also regarded as silence, as compared with what is said in the text. To clarify this point, I would like to refer to the German literary theorist Wolfgang Iser (1926-2007). Under the influence of the Polish phenomenologist Roman Ingarden (1893-1970), he mainly focused on the relationship between an individual text and the reader. According to him, there are lacunae in any literary text. The reader keeps filling the lacunae in creatively so as to understand the text. In Iser's view, "the blank arises out of the indeterminacy of the text." Moreover, fragmentation, as in modern novels, increases the number of blanks (1978, pp. 182 \& 184). Hence, the whole reading experience turns into "an evolving process of anticipation, frustration, retrospection, reconstruction, and satisfaction" (Shi, 2013, p. 985). Through the reading process, while the reader is completing the text, the text also simultaneously gives knowledge to the reader, who has come to the text with a set of social and cultural norms (Iser, 1978, p. 203).

Silence of texts was also taken into consideration from a different aspect in the twentieth century. The French philosopher Jacques Derrida (1930-2004), to whose theories deconstruction owes, showed that

a text (any text-be it a polemic, a philosophical treatise, a poem, or, for that matter, an exercise in deconstructive criticism) can be read as saying something quite different from what it appears to be saying, and that it may read as carrying a plurality of significance or as saying many different things which are fundamentally at variance with, contradictory to and subversive of what may be (or may have been) seen by criticism as a single, stable 'meaning'. (Cuddon, 1999, p. 210)

Pierre Macherey (b. 1938), a French Marxist literary critic, believes, "Silence reveals speech-unless it is speech that reveals the silence" (2006, p. 96). He, in fact, posits that "the hidden or unspoken in the text is the meaning, in a sense exactly parallel to the sense in which the gospel-writers assert that the hidden aspect of the teaching or of the parable $i s$ 
the meaning of the teaching or of the parable." Simply put, things "are made manifest by their environing absences" (Poole, 1985, p. 60).

\section{Knowledge: A Brief Overview}

Knowledge is the crucial way in which we can be drawn out of ourselves and be linked to the outside, to the world (Zagzebski, 2009, p. 1). Questions such as "What is knowledge?" and "How is knowledge acquired?" are within the scope of epistemology. There are several theories which come under the heading of epistemology, theories such as skepticism, empiricism, and positivism. It is commonly regarded as an important field or branch of philosophy although the British-born American anthropologist Gregory Bateson (1904-1980) viewed epistemology as a branch of science (Tsoukas, 2005, p. 3). Nevertheless, the American philosopher Richard Rorty (1931-2007) argued that the "eventual demarcation of philosophy from science was made possible by the notion that philosophy's core was 'theory of knowledge,' a theory distinct from the sciences because it was their foundation. . . Without this idea of a 'theory of knowledge,' it is hard to imagine what 'philosophy' could have been in the age of modern science" (2009, p. 132).

According to the common traditional view traced back to the Greek philosopher Plato (ca. 427-347 BC), knowledge is approximately defined as "justified, true belief. In other words, in order to know that something is the case, one must believe that it is the case, one's belief must be true, and one must be justified (in the internalist sense) in that belief" (Huemer, 2001, pp. 93-94). However, this view has been called into question by Edmund Gettier (b. 1927), an American philosopher, and recently by Timothy Williamson (b. 1955), a British philosopher. Gettier argues that "knowledge requires something beyond justified true belief" (Conee, 2002, p. 180). Williamson contends that "no decompositional analysis of knowledge would be correct because of general problems with definitions and the distinct causal connection between knowledge and behaviour" (Rakova, 2006, p. 97).

According to philosophical doctrines of ancient Greeks, the pursuit and attainment of knowledge was not only the pursuit and achievement of the good of the mind itself but also the main means by which the good life as a whole was found. They said, "Man is more than pure mind, yet mind is his essential distinguishing characteristic, and it is in terms of knowledge that his whole life is rightly directed" (Hirst, 2010, p. 23). As Aristotle (384-322 BC), a Greek philosopher, put it in the first book of Metaphysics (350 BC), "All men by nature desire to know, as is indicated by the love we have for our senses, even apart from their practical uses" (980a21; as cited in Ross, 1975, p. 114).

Other prominent philosophers have also mused over epistemological questions and the significance of knowledge. A few examples are presented here. Sir Francis Bacon (1561-1626), an English philosopher, said that "knowledge itself is power" (as cited in Stagl, 2006, p. 133). John Locke (1632-1704), a British philosopher, identified three types of knowledge: "intuitive, demonstrative, and sensitive" (Ward, 2010, p. 46). However, in general, he regarded knowledge as "the perception of the agreement or disagreement of two ideas" (1836, Ch. I, §2, p. 385). For Karl Marx (18181883), a German philosopher, knowledge "is that activity of man whereby he comes into interaction with the world and understands it so as to transform it." Indeed, "[s]ubjective, non-active apprehension of external reality is knowledge; but it is incomplete-it is mere 'interpretation', mere 'criticism"” (Livergood, 1967, p. 22). Wittgenstein said, "Knowledge is in the end based on acknowledgement" (1969, §378).

Presenting "a symbolic picture of philosophy in the second half of the twentieth century," the German philosopher Peter Munz (1921-2006) stated that there was Karl Popper (1902-1994), an Austrian-British philosopher, on one side, who was "determined to amend some flaws in the Enlightenment by explaining that while induction is no road to knowledge, we can still have rational knowledge by making hypotheses which are falsifiable. If they remain unfalsified, they are taken to be provisionally true. But we must always bear in mind that they might be falsified in the future and replaced by better ones." Wittgenstein and postmodernism were on the other side, "who turned against the Enlightenment with the contention that all knowledge is simply a text which some people agree on and interpret by providing more texts. All these texts are relative to a language-game. Change the rules of the game and the texts will cease to make sense. The question of their truth or falsity cannot even arise" (2004, p. 119).

Nevertheless, knowledge for intellectuals from other fields of study may have a different meaning. For example, for a sociologist, knowledge is "whatever people take to be knowledge. It consists of those beliefs which people confidently hold to and live by. In particular the sociologist will be concerned with beliefs which are taken for granted or institutionalized, or invested with authority by groups of people" (Bloor, 1991, p. 5). Literary figures too have different perspectives on knowledge. In the play Henry VI, part two (1590-1591) by William Shakespeare (1564-1616), Lord Saye says, "And seeing ignorance is the curse of God, / Knowledge the wing wherewith we fly to heaven" (2005, 4.7.72-73). William Blake (1757-1827), an English poet, said, "As the true method of knowledge is experiment, the true faculty of knowing must be the faculty which experiences" (2005, p. 236). Even a historian will maintain a different attitude. For example, the British historian Peter Burke (b. 1937) states that there are knowledges, rather than knowledge, in every culture, including visual knowledge and oral knowledge (Sellers-García, 2014, p. 18).

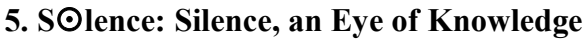

Silence is an eye, eye of knowledge. Through silence, one can see and gain knowledge of so many things. To convey the concept of silence as an eye, I have concocted the word $\mathrm{s} \odot$ lence. $\odot$ in s $\odot$ lence has replaced the letter $\mathrm{i}$, which is pronounced like eye. 
$\odot$ also refers to the gaze, a concept in reflections of Michel Foucault (1926-1984), a French philosopher, and Jacques Lacan (1901-81), a French psychoanalyst. The gaze is integral to our understanding of discourse, knowledge, and power. In Foucault's opinion, "unlike legal power, disciplinary power" controls subjects invisibly. This surveillance depends on what Foucault called "the gaze." "Gazing affects us all as social subjects. We are usually on display and even if not consciously on display we are usually aware that someone may be watching us or monitoring our movements" (Fahy, 2008, p. 5). In fact, the gaze is a relationship between the controller and the controlled-or the colonizer and the colonized, in postcolonial terms - in which the latter is under the control and surveillance of the former. It is worth mentioning that the gaze, as a psychoanalytic concept, was "developed by Lacan following Jean-Paul Sartre's analysis of 'the look' and subsequently adopted in feminist and psychoanalytic film studies, which theorise the ways in which one sees another subject and also comprehends how one is looked at, the human subject comprehends that the other is also a subject" (Wolfreys, Robbins, \& Womack, 2006, pp. 43-44).

Gaze of silence (1932) by Paul Klee (1879-1940), a Swiss painter, is a good example of gaze in art. When one looks at it, one might get surprised to know how one is also looked at by the eye in the painting. My coinage s $\odot$ lence is similar to Klee's Gaze of silence because when you look at it, you are simultaneously looked at by the eye of the s๑lence.

There are examples which substantiate the claim about s๑lence. The Horus story is a remarkable example. Horus was the Egyptian god whom the Greeks called "Harpocratēs." Horus became "popular in Hellenistic times, and is represented as a child holding a finger to his lips, taken to indicate mystery and secrecy; among the Romans he was regarded as the god of silence" (Howatson \& Chilvers, 1993, pp. 249 \& 279). In addition, he was recognized as "one of the greatest sky gods; his eyes were the sun and the moon, and in art he is sometimes Wedjat, the Eye itself" (Leeming, 2005, p. 189). To sum up, Horus as the god of silence was also the Eye from which one could draw the interpretive conclusion that silence is an eye. I regard this eye as an eye of knowledge because, generally speaking, an eye is a symbol "of gods as all-seeing, all-knowing" (Hall, 1995, p. 120). Horus too was a god.

Another example is Ojo de Dios (Spanish, "Eye of God" or "God's Eye"). This folk art object is a colorful weaving of yarn and wood, or strings and sticks. Its center represents a watchful eye. Ojo de Dios is believed to "allow us to see and understand the unknown. God's Eyes bring health and long life" (Stone, 2008, p. 25). In fact, some people use it to not only see the invisible and know the unknown but also remain safe.

It is worth mentioning that weaving is one of the etymological meanings of text (as a means of communication and voice) because the English word text is derived from "L[atin] textum, a thing woven, fabric, style of an author, text of a book. - L[atin] textus, woven, pp. of textere, to weave. + S[anskrit] taksh, to cut wood, to prepare" (Skeat, 1993, p. 501). Furthermore, adopting a postmodern stance, one could regard everything as "a text. Every event is a text, the entire society is a text, and the whole world is a text. . . For example, a woman's face wearing cosmetics is a text" (Kim, 1996, p. 90). Therefore, a painting and a piece of music are also texts (written by an author/writer for a reader). So is Ojo de Dios. Moreover, weaving could remind one of the Philomela story. According to Greek myths, she was raped and, after her tongue was cut out (so as not to sound out a word), she was hid "in a lonely fortress so that she could not reveal what had happened. But Philomela managed to depict her sufferings on a tapestry" (Howatson \& Chilvers, 1993, p. 418). "Her loom so becomes [h]er voice, the story is woven into the design so that her sister Procne may comprehend it" (Trimmer, 2008, p. xiiii). In the end, "Philomela was changed into a swallow (since, having no tongue, she could merely chatter like one) ... (or, according to Latin authors, ... into a nightingale ....)" (Howatson \& Chilvers, 1993, p. 419). Therefore, Ojo de Dios includes two major features: it is an eye (specifically, God's Eye) and is a text (which has no sound but can communicate a message, i.e. give knowledge). The imagery created is similar to that of Horus, the Eye, who held a finger to his lips and therefore was silent.

Cage's 4' 33" (1952) is one more example which supports the idea about $s \odot$ lence. This composition is in three movements. The score reads as follows: "'Tacet. For any instrument or instruments'. The piece is in three movements: 30", 2' 23", and 1' 40"' (Davies, 2005, p. 11). This composition broadened "the definition of music to include imagined as well as heard sounds and silences" (Jorgensen, 2008, p. 135). The silence defamiliarizingly gave the audience an opportunity to be conscious of sounds and noises that came out of not the instruments but the environment. Furthermore, it enriched their understanding of music. Defamiliarization enables us "to 'see' things afresh, according to the theories of some English Romantic poets and of Russian Formalism" (Baldick, 2008, p. 83). It corresponds to Viktor Shklovsky's use of the Russian word ostranenie ("making strange") in his essay Poetry as technique (1917). Shaw-Miller (b. 1960), a professor of History of Art at the University of Bristol, contends that, through John Cage's silence, "the other arts can be seen to be a part of the discourse of music - textual, visual, and theatrical" (2002, p. xii).

That silence is an eye is also seen in Expressionist paintings. As mentioned before, Bahr argued that "Expressionist painting is "eye-music" (Boyd, 1925, pp. 234-35). Indeed, the meaning of silence is "more ambiguous than that of speech" (Jaworski, 1997, p. 4) because the "meaning of silence shifts according to its context and the discourse deploying it" (Dauncey, 2003, p. vii). For instance, silence could be "linguistic (e.g. pause), visual (e.g. monochrome painting) or kinetic (e.g. stillness)" (Jaworski, 1997, p. 4). In painting, the "quality of the silence differs by the nature of the scene as much as by the manner of painting" (Chrétien, 2003, p. 20).

From religious and mystical perspectives, there is a direct relationship between silence, eye, and knowledge. According to Hermes Trismegistus, silence "brings knowledge of the divine" (Long, 2001, p. 62). Two examples are presented here. Hinduism, which is a system of social customs and religious beliefs with adherents particularly in India (Kerr \& 
Wright, 2015, p. 294), recognizes four principal types of yoga. Silence is used in all of them; however, "raja yoga puts special emphasis on concentration and meditation through silence. The principal aim of raja yoga is to lead the seeker of truth through the path of meditation of the highest state of super consciousness where the individual soul communes with the universal spirit in silence and achieves union with it." The truth-seeker is, in fact, in pursuit of right knowledge (Jain \& Matukumalli, 2013, p. 250). Through silent meditation, the truth-seeker's eye of insight, or third eye, opens. This is most prominent in Shiva yoga, which is "the practice of awakening the third eye (sixth chakra) located within the forehead, whose physical manifestation is the pineal gland. In the mystical Hindu tradition, the third eye is the gateway to the inner vision of supreme reality, and the pineal gland is considered to be the organ of cosmic consciousness. The goal of Shiva Yoga is to enhance inner vision to gain access to the innate wisdom that all beings possess but rarely recognize" (Smith, 2014, p. 455).

The second example is about Prophet Mohammad. According to some biographical sources, Mohammad (ca. 570-632), the Arabian prophet of Islam, often retired into a cave near Mecca, called the Hira Cave, located in the Jabal al-Nur (Arabic, "the Mountain of Light"). In this quiet environment which was inaccessible to men and animals, he practiced contemplation and prayed to God with the purposes of enlightenment and purification. It is said that it was in this cave that the initial verses of the Koran were revealed, and known, to him through the archangel Gabriel. Mohammad "spoke of 'true visions' during these moments of retreat, visions that came to him clearly while he was at rest or asleep in the cave of Hira', visions that were 'like the breaking of the light of dawn"' [my italics] (Herlihy, 2012, p. 72). Following Mohammad, some Muslims went into a silent retreat and experienced visionary moments. For example, Ibn al-Arabi (1165-1240) was among these Muslims (Sharifi, 2008, p. 66). He was a distinguished mystic, philosopher, and poet. In his opinion, there are two basic worlds, the visible and the invisible; the outward eye, "sight," perceives the former while the inward eye, "insight," perceives the latter (Chittick, 1989, p. 223). In order to see with the inward eye, the recluse must retreat into a quiet place, practice contemplation, and pray.

To sum up, silence of any kind can expand our knowledge. It was mentioned before that one of the most striking features of the twentieth century which was related to silence was scientific, medical, and technological advances particularly since the first half of the century (Sturken \& Cartwright, 2001, p. 1). As practically understood, the growth of silence in this century was accompanied by the growth of technology, which is defined as "scientific knowledge used in practical ways in industry" [my italics] (Wehmeier, 2005, p. 1576).

\section{Conclusion}

That silence is an eye of knowledge was the central idea I proposed in this article. The considerable significance of silence in the twentieth-century West motivated me to muse over it through reflections of the century's prominent figures including Wittgenstein, Mauthner, Cage, Beckett, Hassan, Kafka, Kandinsky, Sartre, Woolf, Iser, Derrida, and Macherey. This led me to the conclusion that we could acquire knowledge and broaden our understanding through silence. Basically, I believe that silence is not a mere theory, but rather a phenomenon from which we can get practical benefits. To me, silence is never the absence of meaning. This idea is consistent with the views figures such as Dauenhauer, Macherey, and Reik hold. It can provide us with a particular type of literacy. For example, using NoelleNeumann's "spiral of silence" theory, we can gain knowledge of the opinion climate in a society. Moreover, as for a text, by studying such elements as omissions, understatements, and lacunae in it, we can find out more about not only the writer but also his or her social and cultural milieu. Owing to this, I concocted the word s $\odot$ lence, where $\odot$ has been substituted for the letter $i$ and is symbolic of an eye. John Cage's 4' 33", the Horus myth, Ojo de Dios, the nature of Expressionist paintings, a few beliefs in Hinduism, thoughts of Hermes Trismegistus and Ibn al-Arabi, and practices of Mohammad, the prophet of Islam, were explored so as to illuminate the concept of s $\odot$ lence.

\section{References}

Bae, K. J. (2006). Interpreting silence in drama. Journal of English and American Studies, 5, 5-26.

Baldick, C. (2008). The Oxford dictionary of literary terms. New York: Oxford University Press.

Basso, K. H. (1970). "To give up on words": Silence in Western Apache culture. Southwestern Journal of Anthropology, 26(3), 213-230.

Blake, W. (2005). There is no natural religion-I. In W. B. Yeats (Ed.), Collected poems (pp. 236-37). New York: Routledge.

Bloor, D. (1991). Knowledge and social imagery (2nd ed.). Chicago: The University of Chicago Press.

Boyd, E. A. (1925). Studies from ten literatures. New York: C. Scribner's Sons.

Burbules, N. C. (2005). Introduction. In M. Boler (Ed.), Democratic dialogue in education: Troubling speech, disturbing silence (pp. xiii-xxxi). New York: Peter Lang Publishing.

Chittick, W. C. (1989). Ibn al-Arabi's metaphysics of imagination: The Sufi path of knowledge. Albany: State University of New York Press.

Chrétien, J. L. (2003). Hand to hand: Listening to the work of art (S. E. Lewis, Trans.). Fordham University Press. 
Circosta, J. A. (2005). Silence as disclosure: Virginia Woolf's style of being-in-the-world. In A. T. Tymieniecka (Ed.), Analecta Husserliana lxxxvii: Human creation between reality and illusion (pp. 139-53). Dordrecht: Springer.

Colt, G. H. (2006). November of the soul: The enigma of suicide. New York: Scribner.

Conee, E. (2002). Why solve the Gettier problem? In K. B. Wray (Ed.), Knowledge and inquiry: Readings in epistemology (pp. 178-82). Toronto: Broadview Press.

Cuddon, J. A. (1999). Dictionary of literary terms and literary theory. (C. E. Preston, Rev.). New York: Penguin Books.

Dąmbska, I. (2016). Silence as an expression and as a value. In A. Brożek \& J. Jadacki (Eds.), Knowledge, language and silence: Selected papers (pp. 311-18). (K. Cullen, Trans.). Leiden: Brill Rodopi.

Dauncey, S. (2003). The uses of silence: A twentieth-century preoccupation in the light of fictional examples, 19001950. (Doctoral dissertation, University of Warwick). Retrieved from http://wrap.warwick.ac.uk/id/eprint/4054

Davies, S. (2005). Themes in the philosophy of music. New York: Oxford University Press.

Ephratt, M. (2008). The functions of silence. Journal of Pragmatics, 40, 1909-38.

Fahy, K. (2008). Power and the social construction of birth territory. In K. Fahy, M. Foureur, \& C. Hastie (Eds.), Birth territory and midwifery guardianship: Theory for practice, education and research (pp. 3-10). Philadelphia: Elsevier Health Sciences.

Foucault, M. (1980). The history of sexuality, vol. 1: An introduction (R. Hurley, Trans.). New York: Vintage Books. Hall, J. (1995). Illustrated dictionary of symbols in Eastern and Western art. London: John Murray Publishers.

Hegarty, P. (2000). Georges Bataille: Core cultural theorist. London: SAGE Publications.

Herlihy, J. (2012). Islam for our time: Inside the traditional world of Islamic spirituality. Xlibris Corporation.

Hirst, P. H. (2010). Knowledge and the curriculum: A collection of philosophical papers. New York: Routledge.

Hodge, A. N. (2008). The history of art. Berkshire: Arcturus Publishing.

Howatson, M., \& Chilvers, I. (Eds.). (1993). The concise Oxford companion to classical literature. New York: Oxford University Press.

Huemer, M. (2001). Skepticism and the veil of perception. Lanham: Rowman \& Littlefield.

Iser, W. (1978). The act of reading: A theory of aesthetic response. Baltimore: The Johns Hopkins University Press.

Jain, N. C., \& Matukumalli, A. (2013). The functions of silence in India: Implications for intercultural communication research. In M. K. Asante, Y. Miike, \& J. Yin (Eds.), The global intercultural communication reader (2nd ed., pp. 24854). New York: Routledge.

Jaworski, A. (Ed.). (1997). Silence: Interdisciplinary perspectives. New York: Mouton de Gruyter.

Jorgensen, E. R. (2008). The art of teaching music. Bloomington: Indiana University Press.

Kerr, A., \& Wright, E. (Eds.). (2015). A dictionary of world history (3rd ed.). Oxford: Oxford University Press.

Kim, K. L. (1996). Caged in our own signs: A book about semiotics. Westport: Ablex Publishing.

Kramer, L. (2006). "Longindyingcall”: Of music, modernity, and the Sirens. In L. Austern \& I. Naroditskaya (Eds.), Music of the Sirens (pp. 194-215). Bloomington: Indiana University Press.

Laurence, P. O. (1991). The reading of silence: Virginia Woolf in the English tradition. Stanford: Stanford University Press.

Leeming, D. (2005). The Oxford companion to world mythology. New York: Oxford University Press.

Livergood, N. D. (1967). Activity in Marx's philosophy. The Hague: Martinus Nijhoff.

Locke, J. (1836). An essay concerning human understanding (Bk. iv, 27th ed.). London: T. Tegg \& Son.

Long, P. O. (2001). Openness, secrecy, authorship: Technical arts and the culture of knowledge from antiquity to the Renaissance. Baltimore: The Johns Hopkins University Press.

Macherey, P. (2006). A theory of literary production (G. Wall, Trans.). New York: Routledge.

Mackinnell, T. (2011). The Dawning: Shedding new light on the astrological ages. Bloomington: Xlibris Corporation.

Molavi. (1987). Masnavi-e ma'navi (Bk. 4). (R. A. Nicholson, Ed.). Tehran: Amirkabir Publications. [Persian]

Montiglio, S. (2000). Silence in the land of Logos. New Jersey: Princeton University Press.

Munz, P. (2004). My adventure with Popper and Wittgenstein. In P. Catton \& G. Macdonald (Eds.), Karl Popper: Critical appraisals (pp. 114-27). New York: Routledge.

Nakane, I. (2012). Silence. In C. B. Paulston, S. F. Kiesling, \& E. S. Rangel (Eds.), The handbook of intercultural discourse and communication (pp. 158-79). Malden: Blackwell Publishing. 
Parry, B. (1996). Speech and silence in the fictions of J. M. Coetzee. In G. Huggan \& S. Watson (Eds.), Critical perspectives on J. M. Coetzee (pp. 37-65). Basingstoke: Macmillan Press.

Poole, R. (1985). Generating believable entities: Post-Marxism as a theological enterprise. In E. S. Shaffer (Ed.), Comparative criticism. (Vol. 7, pp. 49-71). Cambridge: Cambridge University Press.

Poyatos, F. (2002). Nonverbal communication across disciplines. Volume ii: Paralanguage, kinesics, silence, personal and environmental interaction. Amsterdam: John Benjamins Publishing Company.

Rakova, M. (2006). Philosophy of mind A-Z. Edinburgh: Edinburgh University Press.

Reik, T. (1968). The psychological meaning of silence. Psychoanalytic Review, 55, 172-86.

Richter, D. (2004). Historical dictionary of Wittgenstein's philosophy. Maryland: Scarecrow Press.

Rorty, R. (2009). Philosophy and the mirror of nature (30th-anniversary ed.). Princeton: Princeton University Press.

Ross, W. D. (Ed.). (1975). Aristotle's metaphysics. Oxford: Clarendon Press.

Sartre, J. P. (1962). Camus' The Outsider. In J. P. Sartre, Literary and philosophical essays (pp. 26-44). (A. Michelson, Trans.). New York: Collier Books.

Scheufele, D. A. (2008). Spiral of silence theory. In W. Donsbach \& M. W. Traugott (Eds.), The SAGE handbook of public opinion research (pp.175-83). London: SAGE Publications.

Sellers-García, S. (2014). Distance and documents at the Spanish empire's periphery. Stanford: Stanford University Press.

Shakespeare, W. (2005). 2 Henry VI. In S. Wells \& G. Taylor (Eds.), The Oxford Shakespeare: The complete works. (2nd ed., pp. 55-89). Oxford: Oxford University Press.

Sharifi, M. (2008). Farhang-e adabiyyat-e Farsi [Dictionary of Persian literature] (2nd ed.). (M. R. Jafari, Ed.). Tehran: Farhang-e Nashr-e No' \& Mo'in Publications. [Persian]

Shaw-Miller, S. (2002). Visible deeds of music: Art and music from Wagner to Cage. New Heaven: Yale University Press.

Shi, Y. (2013). Review of Wolfgang Iser and his reception theory. Theory and Practice in Language Studies, 3(6), 982-86.

Skeat, W. W. (Ed.). (1993). Concise dictionary of English etymology. Hertfordshire: Wordsworth Editions.

Smith, L. W. (2014). Our inner ocean: A world of healing modalities. Bloomington: Balboa Press.

Stagl, J. (2006). A history of curiosity: The theory of travel 1550-1800. New York: Routledge.

Stein, G. (1993). What happened: A five act play. In G. Stein, Geography and plays (pp. 205-14). Madison: The University of Wisconsin Press.

Stone, R. (2008). Best practices for teaching social studies: What award-winning classroom teachers do. California: Corwin Press.

Sturken, M., \& Cartwright, L. (2001). Practices of looking: An introduction to visual culture. New York: Oxford University Press.

Trimmer, S. D. (2008). White poetry to the Muse: Poetic works of Steve Trimmer. Bloomington: iUniverse.

Tsoukas, H. (2005). Complex knowledge: Studies in organizational epistemology. Oxford: Oxford University Press.

Ward, L. (2010). John Locke and modern life. Cambridge: Cambridge University Press.

Weagel, D. (2002). Silence in John Cage and Samuel Beckett: 4' 33" and Waiting for Godot. In M. Buning, M. Engelberts, \& S. Houppermans (Eds.), Samuel Beckett today: Pastiches, parodies \& other imitations (pp. 249-62). Amsterdam: Rodopi B. V.

Wehmeier, S. (Ed.). (2005). Oxford advanced learner's dictionary (7th ed.). Oxford: Oxford University Press.

Wittgenstein, L. (1961). Tractatus logico-philosophicus (D. F. Pears \& B. F. McGuinness, Trans.). London: Routledge \& Kegan Paul.

--- (1969). On certainty (G. E. M. Anscombe \& G. H. V. Wright, Eds.; D. Paul \& G. E. M. Anscombe, Trans.). Oxford: Basil Blackwell.

Wolfreys, J., Robbins, R., \& Womack, K. (2006). Key concepts in literary theory (2nd ed.). Edinburgh: Edinburgh University Press.

Woods, T. (1999). Beginning postmodernism. Manchester: Manchester University Press.

Woolf, V. (1990). The voyage out. San Diego: Harcourt Brace Jovanovitch.

Zagzebski, L. (2009). On epistemology. Wadsworth: Cengage Learning.

Zijlstra, O. (2006). Language, image and silence: Kierkegaard and Wittgenstein on ethics and aesthetics. Bern: Peter Lang. 